\title{
Geochemical characteristics of the Toplika manganese- and iron-bearing ore occurrence, central part of the Srednogorie Zone, Bulgaria: Preliminary results
}

\section{Геохимична характеристика на манган- и желязосъдьржащото рудопроявление Топлика, Централно Средногорие, България: предварителни резултати}

\author{
Silvia Chavdarova, Milen Stavrev, Atanas Hikov, Georgi Granchovski, Stoyan Georgiev, \\ Irena Peytcheva \\ Силвия Чавдарова, Милен Ставрев, Атанас Хиков, Георги Грънчовски, Стоян Георгиев, \\ Ирена Пейчева
}

Geological Institute, Bulgarian Academy of Sciences, Acad. G. Bonchev Str., B1. 24, 1113 Sofia;

E-mail: silvia.chavdarova@gmail.com

\begin{abstract}
The growing demand on mineral resources stimulated our interest on manganese- and iron-bearing occurrences as a potential source of $\mathrm{Mn}, \mathrm{Cu}, \mathrm{Ni}, \mathrm{Co}, \mathrm{Mo}, \mathrm{REY}$, etc. Here we focus on the mineralization of the Toplika ore occurrence, which is located in the central part of the Srednogorie Zone, Bulgaria. We present preliminary data on its field relationships, mineralogy and geochemistry and discuss the possible hydrothermal origin of the metalliferous sediments that should be further studies as source of critical elements.
\end{abstract}

Keywords: Toplika, Srednogorie Zone, manganese-iron-bearing ore, critical elements.

\section{Introduction}

The Srednogorie Zone is a main tectono-magmatic and metallogenic unit on the territory of Bulgaria, which is a part of the Median Balkanides (Ivanov, 2017). Extensive magmatism and related ore deposits are characteristic features of the Srednogorie Zone that is considered as a part of the Late Cretaceous Apuseni-Banat-Timok-Srednogorie (ABTS) magmatic and metallogenic belt (e.g. Popov et al, 2002; Gallhofer et al., 2015) on the Balkans. The formation of the ABTS belt is associated with a long-term north-northeast subduction of the Vardar Ocean beneath the European margin (e.g. Boccaletti et al., 1974; Dabovski et al., 1991; Stampfli, Borel, 2004). The Srednogorie Zone is dominated by copper ( $\mathrm{Au}, \mathrm{Mo}$ ) porphyry (i.e. Assarel, Medet, Elatsite, etc.) and epithermal ( $\mathrm{Cu}-\mathrm{Au})$ high sulfidation (Chelopech, Radka, Elshitsa, etc.) ore deposits. However, the volcanic-sedimentary successions in the Panagyurishte region host also manganese- and iron-bearing bodies, which are revealed in the Toplika, Momin Skok, Dalgi Rid, Milkova Cheshma and Spasova Mogila ore occurrences (Dimitrov, Kostov, 1954). The growing demand on mineral resources provoked our interest on these occurrences as the polymetallic nodules of the modern deep sea sediments may bear not only manganese but also series of ore $(\mathrm{Cu}, \mathrm{Zn}, \mathrm{Ni}, \mathrm{Cr})$ and critical elements (REE and $\mathrm{Y}$, V, Co, Li, Nb, Ta) (Hein et al., 2013).

\section{Geological setting}

The object of the present study is the mineralization of the Toplika manganese- and iron-bearing ore occurrence. It is located on the right bank of the Strelchanska Luda Yana River, about $4 \mathrm{~km} \mathrm{NE}$ of Popintsi village. The sediments at Toplika are assigned to the Chelopech and Mirkovo Formations. The Chelopech Formation is composed of volcanosedimentary and volcanic rocks. Marlstones and clayey limestones are observed at different levels. Vertical and lateral alternation is observed between 
sediments, volcanic and mixed rocks. Above it, with an unclear boundary, lies the Mirkovo Formation, which is represented by reddish clayey limestones interbedded with marlstones. Silica-manganese nodules were observed in these rocks. The Mirkovo Formation is overlain, with a normal lithological boundary, by the sediments of the Chugovitsa Formation (Katskov, Iliev, 1993).

\section{Samples and analytical methods}

Over 18 samples of the Toplika occurrence were collected from surface outcrops predominantly at the contact zone of calcareous sediments with volcanic rocks. Eighteen samples for calcareous nannofossil investigation were also taken, at a 1-m resolution, in order to determine or confirm the age of the sediments. Major element mineral composition in analysed samples was obtained by EPMA analyses (SEM JEOL JSM-6610LV) at the University of Belgrade, Serbia. Trace elements were measured by LA-ICPMS (PerkinElmer ELAN DRC-e ICP-MS with New Wave UP193FX LA system) at the Geological Institute, Bulgarian Academy of Sciences. The minerals were also defined by XRD PANalytical Empyrean measurement at the Institute of Physical Chemistry, Bulgarian Academy of Sciences.

\section{Results}

Fieldwork observations revealed single zones of manganese and/or iron-bearing minerals or separate layers $(5-15 \mathrm{~cm})($ Fig. 1a, b) and lenses among the reddish clayey limestones from the Chelopech and Mirkovo Formations. Often, the ore samples are crossed by quartz-chalcedony veinlets (Fig. 1a, c). There is one main ore body, which is more than $20 \mathrm{~m}$ long and 4-5 $\mathrm{m}$ tick (Fig. 1d, e).

Samples for calcareous nannofossil investigation yielded depauperate assemblages with low taxonomic diversity. Specimens have been affected by secondary calcite dissolution and/or overgrowth. The most frequently observed taxa are Watznaueria barnesiae and Eiffellithus eximius, followed by Tranolithus orionatus, Helicolithus anceps and Prediscosphaera cretacea. Rare to frequent Micula adumbrata, Micula staurophora, Arkhangelskiella confusa, Lucianorhabdus cayeuxii, Quadrum gartneri, Micula cf. M. swastica and very rare to rare Broinsonia parca ssp. expansa were also noted. No specimens of Lithastrinus septenarius were detected. Due to the poor preservation of the nannofloras, it cannot be determined whether the absence of the latter species is a primary signal or not. Thus, the studied sediments have tentatively been assigned to the middle Coniacian-Santonian.

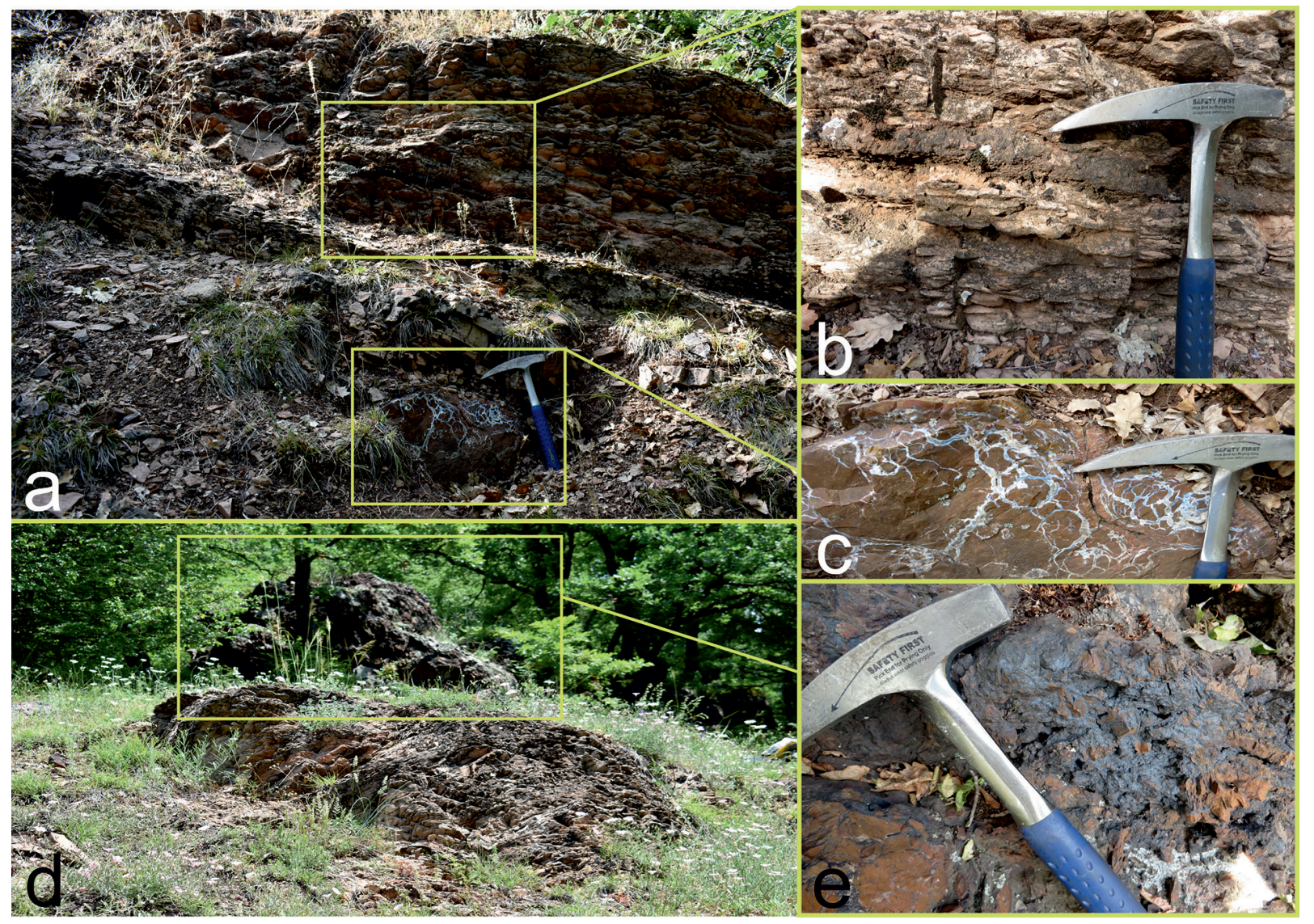

Fig. 1. Field photographs of the Toplika ore occurrence: $a$, outcrop of reddish clayey limestones, including thin layer-like ore body; $b$, silica nodule cut by late chalcedony veinlets $(c) ; d$, the main outcrop with manganese and iron-bearing minerals $(e)$ 
The main manganese minerals from the Toplika manganese- and iron-bearing ore occurrence are pyrolusite and todorokite. Traces of sarkinite, hauerite and hematite are defined by XRD analyses. The gangue minerals are quartz, calcite and zeolites. The manganese minerals form mainly spherolitic textures alternating with silica-bearing phases. Based on the ratio of the major elements $\mathrm{Mn}$ and $\mathrm{Si}$ we divided the established mineral phases in two groups: (i) manganese and (ii) silica-manganese phases. In the first group, the major oxides vary as follows: $\mathrm{MnO}(47.15-82.04 \mathrm{wt} \%)$, $\mathrm{FeO}_{\mathrm{t}}(1.08-6.27 \mathrm{wt} \%)$, and $\mathrm{SiO}_{2}(0.49-2.01 \mathrm{wt} \%)$. In the second group the $\mathrm{SiO}_{2}$ content increases substantially $\left(\mathrm{SiO}_{2} 8.95-72.83 \mathrm{wt} \%\right)$, whereas the content of the other major oxides decreases and vary for $\mathrm{MnO}$ (11.05$58.23 \mathrm{wt} \%)$ and $\mathrm{FeO}_{\mathrm{t}}(0.56-1.79 \mathrm{wt} \%)$. Other minor elements/oxides that were detected by EPMA analyses are $\mathrm{BaO}(1.25-12.59 \mathrm{wt} \%), \mathrm{Al}_{2} \mathrm{O}_{3}(0.33-0.67 \mathrm{wt} \%)$, $\mathrm{K}_{2} \mathrm{O}(0.23-0.40 \mathrm{wt} \%)$, and $\mathrm{CaO}(0.17-1.21 \mathrm{wt} \%)$.

The trace element composition in the studied samples with manganese (i) and silica-manganese (ii) phases is characterized by higher content of $\mathrm{V}$ (132-868 ppm), Zn (79-620 ppm), Mo (124-637 ppm), and W (49-253 ppm). In the first group other trace elements above the limit of detection are Co (4-98 ppm), Ni (46-517 ppm), Cu (253-1017 ppm), and Sr (162$8161 \mathrm{ppm})$. There is a slight difference in the trace elements content in the group with silica-manganese phases where the variations are: $\mathrm{Co}(27-258 \mathrm{ppm}), \mathrm{Ni}$ (12-71 ppm), Cu (88-484ppm), Sr (292-6912 ppm), and $\mathrm{Tl}(4.76-119 \mathrm{ppm})$.

\section{Discussion and conclusions}

The Mn- and Fe- ore occurrences in the Panagyurishte ore region are deposited on the contact zones between Upper Cretaceous andesitic breccias/andesites and reddish clayey limestones. Our working hypothesis for their genesis is in accordance with Dimitrov and Kostov (1954) considering the nodules at Toplika as initially gel-like masses, subsequently partially dehydrated during diagenesis. At the end of the lithification process, the nodules and nodule-like bodies reduced their volume, whereas concentric and irregular cracks have been formed. Late chalcedony and quartz veinlets cross-cut the earlier mineral phases. The same authors discussed the link of ore-formation to hydrothermal process. In the study area some evidence for hydrothermal origin of the nodules are the brecciated quartz bodies, cemented by $\mathrm{Mn}$ - and Fe-bearing ore mineralization that are established at the contact between the volcanics and sediments in the study area. These bodies can be considered as hydrothermal breccias.

The described samples from the Toplika manganese- and iron-bearing ore occurrence show some mineral and geochemical similarities with deep-sea polymetallic nodules and metalliferous sediments. These deep-sea nodules are enriched in $\mathrm{Mn}$ and $\mathrm{Fe}$, as well as $\mathrm{Cu}, \mathrm{Co}, \mathrm{Ni}$, Mo and W (Hein et al., 2013). It is characteristic that our samples contain also significant amounts of manganese and iron, and traces of $\mathrm{Ba}, \mathrm{Cu}$, $\mathrm{Sr}, \mathrm{V}$, and Ni. However, there are also some differences in the mechanism of formation, the degree of lithification and type of sedimentation, as the ore samples from Toplika are found in shallower sediments. The deep-sea calcareous sedimentation through the Coniacian, Santonian and Campanian has a hemipelagic character; consequently the carbonate deposition proceeded at depths between $200 \mathrm{~m}$ and $4000 \mathrm{~m}$ (Nachev, Nachev, 1986).

Further field, mineral-petrological and geochemical studies on the Toplika and other Mn-Fe ore occurrences from Panagyurishte region are needed to better constrain their origin, mineral and geochemical features and potential as a possible source of metals and critical elements.

Acknowledgements: The study was supported by the Bulgarian National Science Fund, grant KP$06-\mathrm{N} 34 / 6$.

\section{References}

Boccaletti, M., P. Manetti, A. Peccerillo. 1974. Hypothesis on plate tectonic evolution of Carpatho-Balkan Arcs. - Earth Planet. Sci. Lett., 23, 193-198; https://doi. org/10.1016/0012-821x(74)90193-9.

Dabovski, C., A. Harkovska, B. Kamenov, B. Mavroudchiev, G. Stanisheva-Vassileva, Y. Yanev. 1991. A geodynamic model of the Alpine magmatism in Bulgaria. - Geologica. Balc., 21, 3-15.

Dimitrov, Ts., I. Kostov, 1954. On the genesis of manganese ore deposits in Srednogorie. - Ann. Univ. Sofia, 48, 2-géol., 24-61 (in Bulgarian with English abstract).

Ivanov, Z. 2017. Tectonics of Bulgaria. Sofia, St. Kliment Ohridski Univ. Press, 332 p. (in Bulgarian with English abstract).

Gallhofer, D., A. von Quadt, I. Peytcheva, S. Schmid, C. Heinrich. 2015. Tectonic, magmatic, and metallogenic evolution of the Late Cretaceous arc in the CarpathianBalkan orogen. - Tectonics, 34, 1813-1836; https://doi. org/10.1002/2015TC003834.

Hein, J., K. Mitzell, A. Koschinsky, T. Conrad. 2013. Deepocean mineral deposits as a source of critical metals for high- and green-technology applications: Comparison with land-based resources. - Ore Geol. Rev., 51, 1-14; https:// doi.org/10.1016/j.oregeorev.2012.12.001.

Katskov, N., K. Iliev. 1993. Explanation Notes to the Geological Map of Bulgaria in Scale 1:100 000. Map Sheet Panagyurishte. Sofia, Ministry of Environment and Water and Bulgarian Geological Survey, 54 p. (in Bulgarian).

Nachev, I., Ch. Nachev. 1986. Sedimentology of the Upper Cretaceous in the Panagyurishte district. II. Interpretation of results. - Paleontol., Stratigr. and Lithol., 23, 65-77 (in Bulgarian with English abstract).

Popov, P., T. Berza, A. Grubic, D. Ioane. 2002. Late Cretaceous Apuseni-Banat-Timok-Srednogorie (ABTS) magmatic and metallogenic belt in the Carpathian-Balkan orogen. - Geologica Balc., 32, 2-4, 145-163.

Stampfli, G. M., G. D. Borel. 2004. The TRANSMED transects in space and time: constraints on the paleotectonic evolution of the Mediterranean domain. - In: Cavazza, W., F. Roure, W. Spakman, G. M. Stampfli, P. A. Ziegler (Eds.). The TRANSMED Atlas, The Mediterranean Region from Crust to Mantle. Berlin, Springer, 53-80; https://doi. org/10.1007/978-3-642-18919-7_3. 